TITLE:

\title{
Diversity of Family Fungiidae in Malaysian Waters
}

$\operatorname{AUTHOR}(\mathrm{S})$ :

TAN SHAU HWAI, AILEEN; ISMAIL, ISYAM ASUANDI; YASIN, ZULFIGAR

\section{CITATION:}

TAN SHAU HWAI, AILEEN ... [et al]. Diversity of Family Fungiidae in Malaysian Waters.

Publications of the Seto Marine Biological Laboratory. Special Publication Series 2009, 9: 15-24

ISSUE DATE:

2009

URL:

http://hdl.handle.net/2433/144633

RIGHT: 


\title{
Diversity of Family Fungiidae in Malaysian Waters
}

\author{
Aileen Tan Shau Hwai*, Isyam Asuandi Ismail and Zulfigar Yasin \\ School of Biological Sciences Universiti Sains Malaysia \\ 11800 Penang MALAYSIA \\ Corresponding author's e-mail: aileen@usm.my
}

\begin{abstract}
Diversity of the family Fungiidae was investigated in Malaysian waters during an expedition in 2004. From the samples collected on 18 reef locations around Malaysian waters, only 12 locations contained fungiid corals. From the locations that have fungiid corals, 11 species from five genera were recorded. They are Fungia (Ctenactis) echinata, Fungia (Ctenactis) simplex, Fungia (Danafungia scruposa, Fungia (Danafungia) danai, Fungia (Fungia) fungites, Fungia (Pleuractis) paumotensis, Fungia (Pleuractis) scutaria, Halomitra pileus, Sandalolitha robusta, Herpolitha limax and Polyphyllia talpina. The diversity of the fungiid corals at Hempasan Dang Ajar and Terumbu Peninjau far outweighs all other sites with six different species at each location. Other locations have three species on average. Out of 11 species of Fungiidae coral, Sandalolitha robusta and Herpolitha limax are the most commonly found species. They are found on seven sampling locations each. The rarest species are Fungia simplex, Fungia scruposa and Fungia paumotensis which can be found at only one sampling location each. Other available species could be found at three locations on average. This study has reported higher number of fungiid species compared to previous studies done in Peninsular Malaysia but similar with the study done in Singapore.
\end{abstract}

Key words: Taxonomy, morphological features, fungiid corals, species, genera

\section{Introduction}

Coral Family Fungiidae derived their name from the Latin word fungus, which means mushroom, to describe the mushroom-like appearance of most specimens. The fungiid corals are commonly sited amongst the diverse growth of a coral reef community and are one of the most conspicuous groups of extant Indo-Pacific reef in Order Scleractinia. They are almost all distinctively solitary free-living coral, partially mobile and uniquely shaped. Most of the free-living fungiid are small in size to assist in their mobility. The most noticeable features of the mushroom corals are their immense polyp size. Indeed, the polyps of fungiids are among the largest known, with Heliofungia measuring over $50 \mathrm{~cm}$ in diameter (Veron, 1993).

Peninsular and East Malaysia are situated on the Sunda Shelf in relatively shallow water. Coral diversity is relatively low on the west coast of Peninsular Malaysia's reef compared to the east coast of Peninsular Malaysia's reefs due to turbid conditions and muddy substrates (Chua \& Charles, 1980). Malaysian reefs and their coral fauna have been reasonably well studied. Searle (1980) produced a key to 78 species of corals from Peninsular Malaysia, and this work has been updated and expanded by Betterton (1981). However, until relatively recently, very little was known about the life history and ecology of this fascinating group of corals from the Family Fungiidae, especially those distributed on the reefs located at the South China Sea.

This study aims to investigate the diversity of the Fungiidae from the reefs surrounding the South China Sea. Sampling was conducted during the Research on the Seas and Islands of Malaysia (ROSES) Expedition in 2004. This study also compares the diversity of Family Fungiidae sampled 
during the ROSES expedition with other reef locations.

\section{MATERIALS AND METHODS}

\section{Study sites}

Research on the Seas and Islands of Malaysia (ROSES) Expedition was an ambitious project which aimed to explore the richness of Malaysia's marine realm for the Science of Biotechnology and Biodiversity. During the ROSES expedition, 18 reef locations were sampled. They are Pulau Perak, Pulau Jarak, Permatang Penyu (Vernon Bank), Terumbu Peninjau (Investigator Reef), Permatang Ubi (Ardasier Bank), Terumbu Laya (Dallas Reef), Pulau Layang-layang, Terumbu Matanani (Mariveles Reef), Terumbu Siput (Erica Reef), Terumbu Semarang Barat Besar (Royal Charlotte Reef), Terumbu Semarang Barat Kecil (Louisa Reef), Terumbu Permaisuri (Moody Reef), Terumbu Asun (Hardie Reef), Terumbu Dato' Landih (Aitken Reef), Hempasan Dang Ajar (Seahorse Breakers), Terumbu Sahab (Stigan Reef), Terumbu Saji (Herald Reef) and Hempasan Bantin (Luconia Breakers). Most of these reefs are fringing reefs with gradual slope to a maximum depth of between $35-50 \mathrm{~m}$. The sites and their approximate coordinates are listed in Table 1 and mapped in Figure 1.

These reefs were relatively unstudied before as most of them occur too far off the coast to be accessible enough for elaborate research to be conducted. The reefs depth ranged from as low as $4 \mathrm{~m}$ to a maximum depth of approximately $30 \mathrm{~m}$. Pulau Perak, which is situated west of Pulau Pinang and in the middle of the Straits of Malacca, is a $200 \mathrm{~m}$ wide conical rocky island with the steep slope continuing underwater to a depth of about $50 \mathrm{~m}$. Pulau Jarak is also located in the Straits of Malacca.

\section{Sampling method}

The line transect method which covered between $100-150 \mathrm{~m}$ by $2 \mathrm{~m}$ swath per transect were conducted using SCUBA. The samplings were conducted from the base of the coral rich zone $(\sim 30$ $\mathrm{m})$ to shallow water $(<5 \mathrm{~m})$. An initial descent was generally made to the base of the reef but occasionally the surveys started beyond the maximum depth of abundant coral growth. Distances of area surveyed were calculated and the numbers of same species were converted into Relative Abundance unit (individual per $100 \mathrm{~m}^{2}$ ). The time constraint of the expedition (43 days) meant that sampling frequency on each reef is low on many occasions where some of the reefs were only sampled once. Field guides assisted identification was used underwater. However, a number of species were sighted which could not be identified, photographs were taken underwater or the samples were collected to be identified later in the laboratory.

\section{Sample preparation and identification}

Samples that were removed from the sea were washed with freshwater to eliminate some of the live tissues of the sample. It is more efficient to wash the samples with high pressurized jet of freshwater. This process could reduce part of the coral's organic materials. Samples that were washed are then dried under direct sunlight covered with newspaper. The newspaper acts as an absorber of the smell and has to be changed occasionally.

When the samples are dry, it is then left submerged in 5.25\% solution of natrium hypochlorite or bleach solution that has been diluted with freshwater. Dilution ratios are bleach solution to freshwater, 1:4 for delicately structured samples and 1:2 for heavily calcified samples. Samples are left in said solution for 24 or 48 hours until they are white. Samples are washed with freshwater and dried under direct sunlight again. Dried samples are odourless and stored in a room with sufficient airflow to keep the samples safe from damage due to excess moisture.

All the sample corals were identified in the laboratory at Muka Head Marine Research Station, 
Table 1. Reef locations and their approximate coordinates.

\begin{tabular}{|c|c|c|}
\hline Location & Location (Sampling Site) & $\begin{array}{l}\text { Approximate } \\
\text { Coordinates }\end{array}$ \\
\hline \multirow{4}{*}{ Straits of Malacca } & Pulau Perak & $\mathrm{N} \quad 5^{\circ} 41^{\prime} 16.1^{\prime \prime}$ \\
\hline & & E $98^{\circ} 57^{\prime} 24.0^{\prime \prime}$ \\
\hline & Pulau Jarak & $\mathrm{N} \quad 3^{\circ} 58^{\prime} 31.5^{\prime \prime}$ \\
\hline & & $\mathrm{E} 100^{\circ} 05^{\prime} 39.1^{\prime \prime}$ \\
\hline \multirow{18}{*}{$\begin{array}{l}\text { South China Sea } \\
\text { off the west coast of Sabah }\end{array}$} & Permatang Penyu & $\mathrm{N} \quad 5^{\circ} 50^{\prime} 03.5^{\prime \prime}$ \\
\hline & (Vernon Bank) & $\mathrm{E} 115^{\circ} 06^{\prime} 09.3^{\prime \prime}$ \\
\hline & Terumbu Peninjau & $\mathrm{N} \quad 8^{\circ} 07^{\prime} 58.3^{\prime \prime}$ \\
\hline & (Investigaor Reef) & $\mathrm{E} 114^{\circ} 47^{\prime} 56.6^{\prime \prime}$ \\
\hline & Permatang Ubi & $\mathrm{N} \quad 7^{\circ} 56^{\prime} 42.3^{\prime \prime}$ \\
\hline & (Ardasier Bank) & $\mathrm{E} 114^{\circ} 26^{\prime} 00.0^{\prime \prime}$ \\
\hline & Terumbu Laya & $\mathrm{N} \quad 7^{\circ} 36^{\prime} 40.7^{\prime \prime}$ \\
\hline & (Dallas Reef) & $\mathrm{E} 113^{\circ} 44^{\prime} 47.0^{\prime \prime}$ \\
\hline & Pulau Layang-Layang & $\mathrm{N} \quad 7^{\circ} 22^{\prime} 47.6^{\prime \prime}$ \\
\hline & & $\mathrm{E} 113^{\circ} 50^{\prime} 36.2^{\prime \prime}$ \\
\hline & Terumbu Mantanani & $\mathrm{N} \quad 7^{\circ} 58^{\prime} 36.0^{\prime \prime}$ \\
\hline & (Mariveles Reef) & $\mathrm{E} 113^{\circ} 54^{\prime} 07.8^{\prime \prime}$ \\
\hline & Terumbu Siput & $\mathrm{N} 8^{\circ} 05^{\prime} 57.1^{\prime \prime}$ \\
\hline & (Erica Reef) & E114 $07^{\circ} 54.7^{\prime \prime}$ \\
\hline & Terumbu Semarang Barat Besar & N 6 $6^{\circ} 20^{\prime} 09.0^{\prime \prime}$ \\
\hline & (Royal Charlotte Reef) & $\mathrm{E} 113^{\circ} 34^{\prime} 36.1^{\prime \prime}$ \\
\hline & Terumbu Semarang Barat Kecil & $\mathrm{N} \quad 6^{\circ} 20^{\prime} 09.0^{\prime \prime}$ \\
\hline & (Louisa Reef) & $\mathrm{E} 113^{\circ} 13^{\prime} 48.2^{\prime \prime}$ \\
\hline \multirow{8}{*}{$\begin{array}{l}\text { Gugusan Beting Raja Jarom } \\
\text { (North Luconia Shoals) }\end{array}$} & Terumbu Pemaisuri & $\mathrm{N} \quad 5^{\circ} 35^{\prime} 29.8^{\prime \prime}$ \\
\hline & (Moody Reef) & $\mathrm{E} 112^{\circ} 32^{\prime} 24.1^{\prime \prime}$ \\
\hline & Terumbu Asun & $\mathrm{N} \quad 5^{\circ} 50^{\prime} 57.0^{\prime \prime}$ \\
\hline & (Hardie Reef) & $\mathrm{E} 112^{\circ} 28^{\prime} 09.1^{\prime \prime}$ \\
\hline & Terumbu Dato' Landih & $\mathrm{N} \quad 5^{\circ} 53^{\prime} 22.7^{\prime \prime}$ \\
\hline & (Aiken Reef) & E11232'26.7'” \\
\hline & Hempasan Dang Ajar & $\mathrm{N} \quad 5^{\circ} 30^{\prime} 14.6^{\prime \prime}$ \\
\hline & (Seahorse Breakers) & E112 $34^{\prime} 47.2^{\prime \prime}$ \\
\hline \multirow{6}{*}{ Gugusan Beting Patinggi Ali } & Terumbu Sahab & $\mathrm{N} \quad 5^{\circ} 01^{\prime} 15.4^{\prime \prime}$ \\
\hline & (Stigan Reef) & $\mathrm{E} 112^{\circ} 28^{\prime} 37.4^{\prime \prime}$ \\
\hline & Terumbu Saji & $\mathrm{N} \quad 4^{\circ} 58^{\prime} 30.6^{\prime \prime}$ \\
\hline & (Herald Reef) & $\mathrm{E} 112^{\circ} 36^{\prime} 28.2^{\prime \prime}$ \\
\hline & Hempasan Bantin & $\mathrm{N} \quad 5^{\circ} 01^{\prime} 22.9^{\prime \prime}$ \\
\hline & & $\mathrm{E} 112^{\circ} 38^{\prime} 28.9^{\prime \prime}$ \\
\hline
\end{tabular}

Universiti Sains Malaysia using taxonomic keys from various books such as Betterton (1981), Koh and Chou (1989) and Veron (1993). Samples were analyzed with the help of a magnifying glass although in some cases, the septa and costae features are too minute and the help of a dissection microscope is sought.

\section{Physical and chemical data sampling}

Physical (Temperature, salinity and dissolved oxygen) and chemical (nitrate and phosphate) data were collected throughout the expedition using Hydrolab Data Sonde 4, except for total suspended 

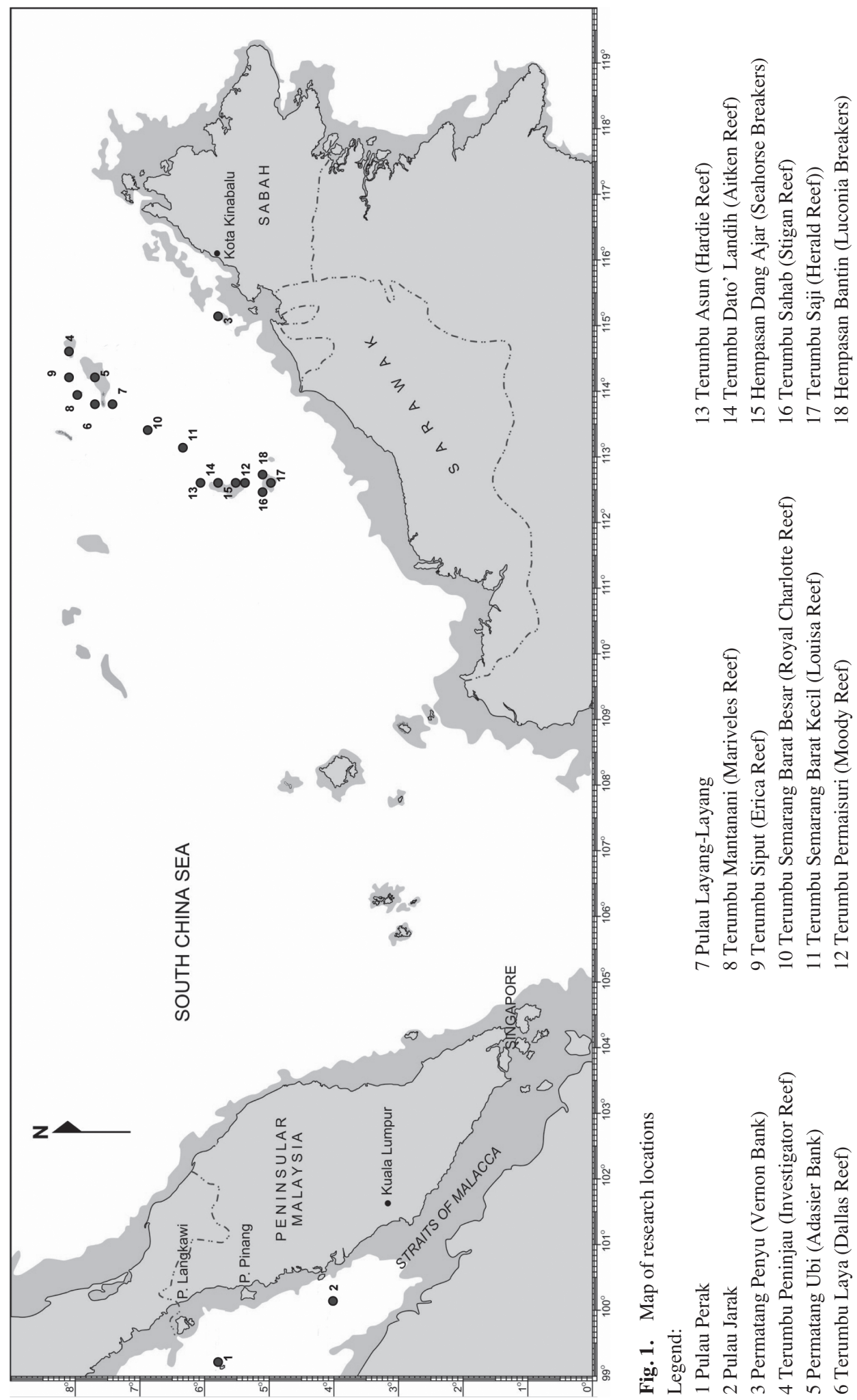
solid measurement. Total suspended solid measurement was carried out based on AHPA (1992) by drying method at $103-105^{\circ} \mathrm{C}$.

\section{RESULTS AND DISCUSSION}

Of all the 18 reef locations that were sampled, only 12 locations contained Fungiidae corals. The locations are Pulau Perak, Terumbu Peninjau (Investigator Reef), Permatang Ubi (Ardasier Bank), Terumbu Laya (Dallas Reef), Terumbu Matanani (Mariveles Reef), Terumbu Semarang Barat Besar (Royal Charlotte Reef), Terumbu Semarang Barat Kecil (Louisa Reef), Terumbu Permaisuri (Moody Reef), Terumbu Asun (Hardie Reef), Terumbu Dato' Landih (Aitken Reef), Hempasan Dang Ajar (Seahorse Breakers) and Hempasan Bantin (Luconia Breakers). The remaining six locations devoid of fungiid coral samples are Pulau Jarak, Permatang Penyu (Vernon Bank), Pulau Layang-layang, Terumbu Siput (Erica Reef), Terumbu Sahab (Stignan Reef) and Terumbu Saji (Herald Reef). The availability and the relative abundance of the species of corals according to the reef locations is shown in Table 2.

The diversity of the fungiid corals at Hempasan Dang Ajar and Terumbu Peninjau far outweighs all other sites with a record of six different species at each location, with 12 and 15 individuals per $100 \mathrm{~m}^{2}$, respectivey. Terumbu Permaisuri, Terumbu Asun and Terumbu Dato' Landih have three different fungiid species each. Terumbu Matanani, Terumbu Semarang Barat Besar and Terumbu Semarang Barat Kecil each contain two different fungiid species while Pulau Perak and Terumbu Laya each contain one species. Figure 2 shows the number of fungiid species found at each reef location.

The results indicated that 11 species from five genera were found. Of the 11 species found, the most common was Sandadolitha robusta and Herpolitha limax - which was found on seven sampling locations. The rarest of the species was Fungia simplex, F. scruposa and F. paumotensis, which was found only on one location each.

Meanwhile, $F$. fungites was found in the Straits of Malacca - at Pulau Perak. No fungiids were found in Pulau Jarak. The low diversity of fungiids in the Straits of Malacca may be due to the higher total suspended solids and lower surface salinity (Table 3), compared to the reefs located at the South China Sea. However, F. fungites was also found at Terumbu Peninjau and Permatang Ubi (both of the Layang-layang group) in the South China Sea indicating the environmentally tolerant nature and wider distribution of the species.

Fungia echinata could be found at five locations. Fungia scutaria can be found at four locations. Fungia fungites, Halomitra pileus and Polyphillia talpina could be found at three locations each. Fungia danai could be found at two locations. Figure 3 summarizes the distribution of fungiid corals in the reef locations.

Five genera and 11 species have been recorded in this study and this reflects a lower diversity of fungiid corals compared to the 11 genera and 34 species of fungiid corals reported by Veron (1993) of the Indo-Pacific corals, and 6 genera and 13 species of fungiids by Koh and Chou (1989) from southern Singapore. Veron (1993) had reported a high diversity of Fungiidae corals because the area covered in his work is very wide (Indo-Pacific) compared to this study which only covered the Straits of Malacca and the central of South China Sea. The low diversity of fungiids in Malaysian waters may be due to the limited numbers of samplings being carried out as well as the sampling coverage for each sampling locations during the expedition. 


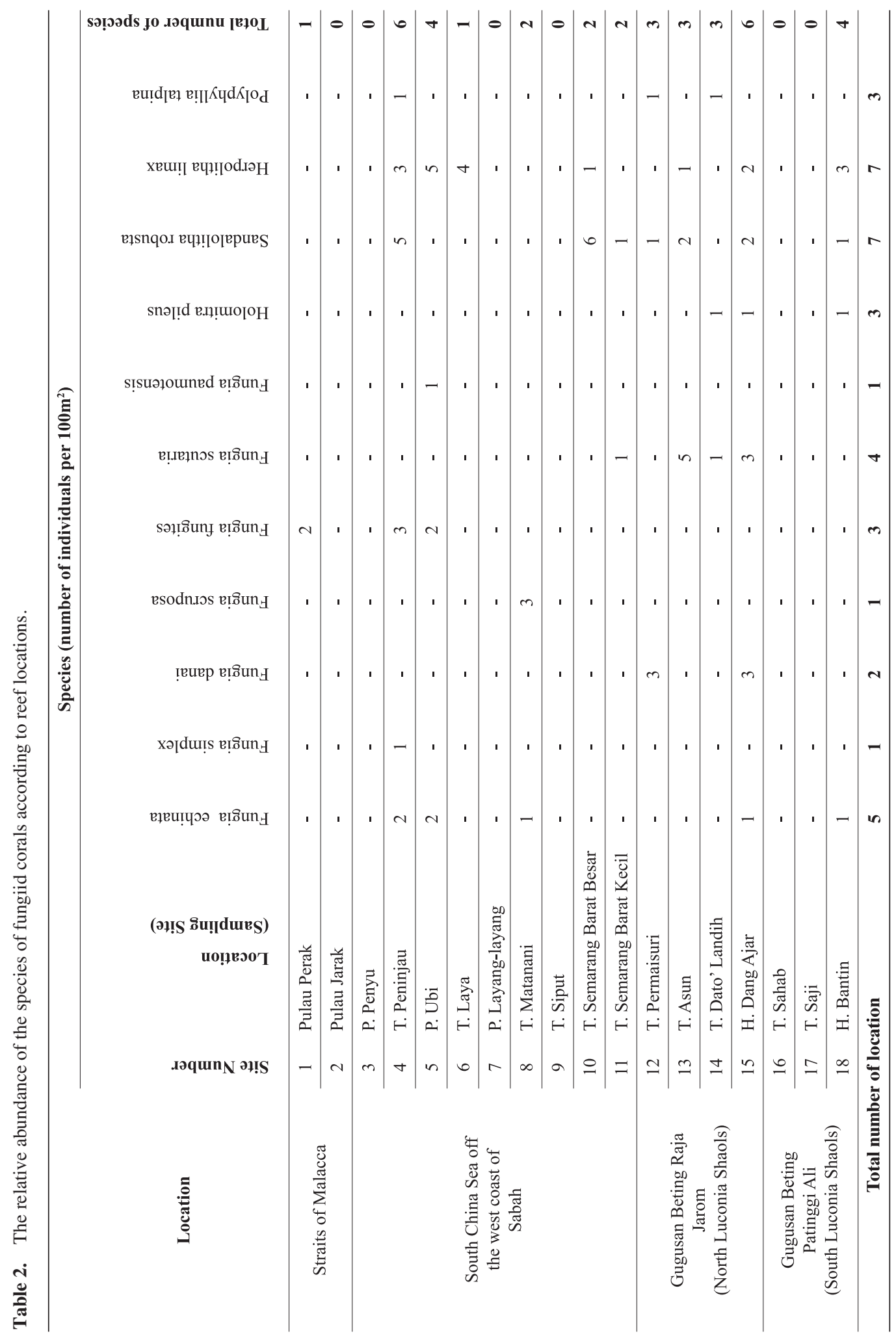




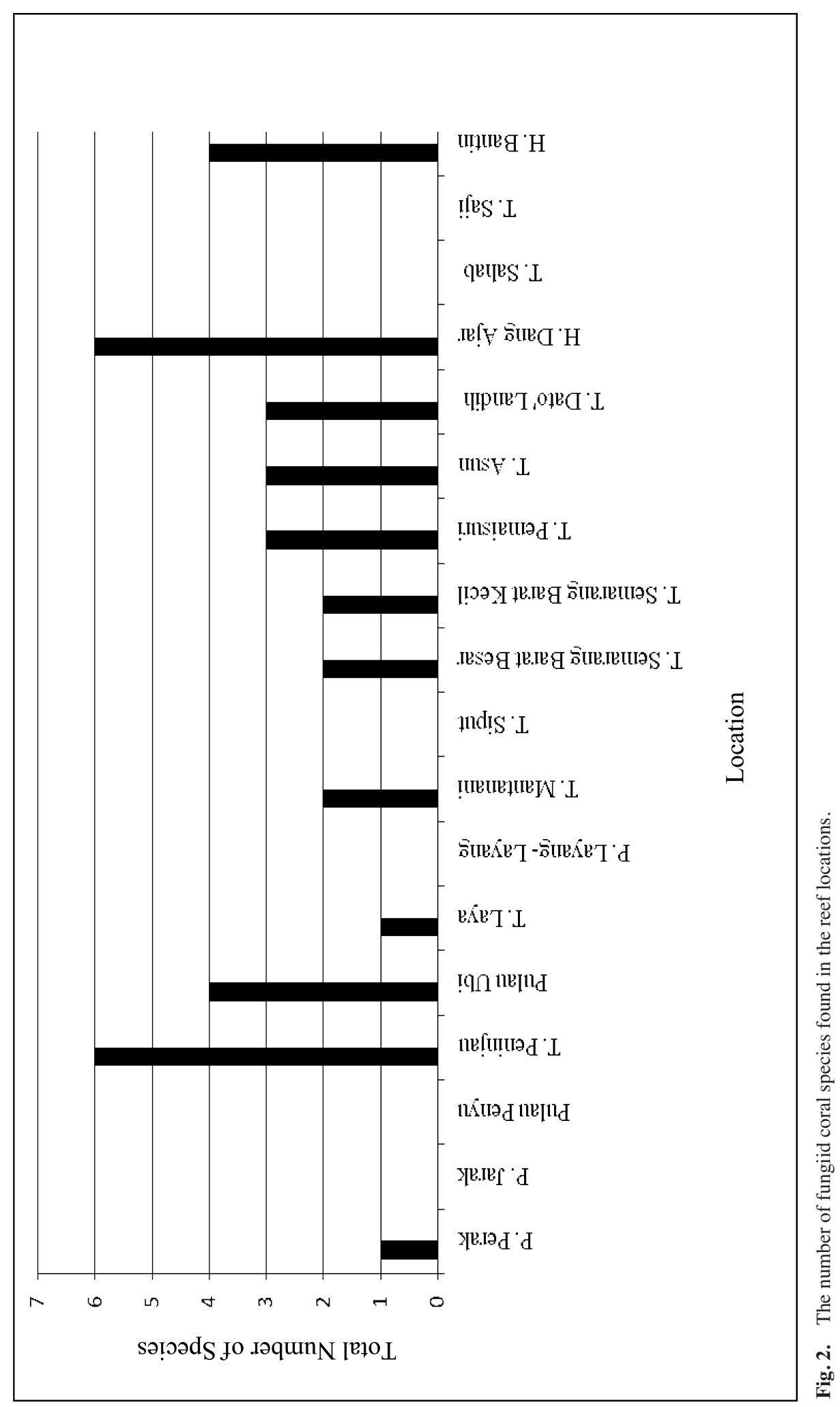


Table 3. Data of physical and nutrient parameters obtained from Hydrolab Data Sonde 4A during the sampling.

\begin{tabular}{|c|c|c|c|c|c|c|c|c|}
\hline Location & Sampling Site & $\underset{{ }^{\circ} \mathrm{C}}{\text { Temperature }}$ & $\begin{array}{l}\text { Salinity } \\
\text { (ppt) }\end{array}$ & $\underset{\text { (units) }}{\mathrm{pH}}$ & $\begin{array}{c}\text { D.O } \\
(\mathrm{mg} / \mathrm{L})\end{array}$ & $\begin{array}{c}\text { Total } \\
\text { suspended } \\
\text { Solid } \\
(\mathrm{mg} / \mathrm{L})\end{array}$ & $\begin{array}{l}\text { Nitrate } \\
\text { (mg/L) }\end{array}$ & $\begin{array}{c}\text { Phosphate } \\
\text { (mg/L) }\end{array}$ \\
\hline \multirow{2}{*}{$\begin{array}{l}\text { Straits of } \\
\text { Malacca }\end{array}$} & Pulau Perak & 29.26 & 30.21 & 8.28 & 5.42 & 43.89 & 0.13 & 0.01 \\
\hline & Pulau Jarak & 29.69 & 30.05 & 8.29 & 5.43 & 48.67 & 0.13 & 0.02 \\
\hline \multirow{9}{*}{$\begin{array}{c}\text { South China Sea } \\
\text { off the west coast } \\
\text { of Sabah }\end{array}$} & Permatang Penyu & 29.04 & 33.97 & 8.28 & 5.38 & 22.17 & 0.08 & 0.04 \\
\hline & Terumbu Peninjau & 29.24 & 33.83 & 8.06 & 5.58 & 21.68 & 0.08 & 0.01 \\
\hline & Permatang Ubi & 29.56 & 33.76 & 8.06 & 5.56 & 19.32 & 0.06 & 0.01 \\
\hline & Terumbu Laya & 29.34 & 33.75 & 8.07 & 5.59 & 21.45 & 0.09 & 0.02 \\
\hline & Pulau Layang-layang & 29.51 & 33.73 & 8.07 & 5.59 & 20.17 & 0.09 & 0.02 \\
\hline & Terumbu Mantanani & 29.60 & 33.78 & 8.06 & 5.56 & 24.81 & 0.09 & 0.02 \\
\hline & Terumbu Siput & 29.44 & 33.83 & 8.06 & 5.59 & 23.56 & 0.09 & 0.01 \\
\hline & Terumbu Semarang Barat & 29.49 & 33.89 & 8.30 & 5.71 & 21.95 & 0.00 & 0.03 \\
\hline & Terumbu Semarang Barat Kecil & 29.46 & 33.86 & 8.30 & 5.69 & 14.65 & 0.04 & 0.03 \\
\hline \multirow{4}{*}{$\begin{array}{l}\text { Gugusan Beting } \\
\text { Raja Jarom }\end{array}$} & Terumbu Permaisuri & 30.35 & 33.84 & 8.21 & 6.06 & 22.08 & 0.04 & 0.01 \\
\hline & Terumbu Asun & 29.01 & 33.98 & 8.28 & 6.05 & 20.47 & 0.09 & 0.01 \\
\hline & Terumbu Dato' Landih & 28.92 & 33.92 & 8.28 & 6.05 & 22.56 & 0.04 & 0.00 \\
\hline & Hempasan Dang Ajar & 29.73 & 33.57 & 8.27 & 6.05 & 18.64 & 0.04 & 0.02 \\
\hline \multirow{3}{*}{$\begin{array}{l}\text { Gugusan Beting } \\
\text { Patinggi Ali }\end{array}$} & Terumbu Sahab & 30.61 & 33.54 & 8.20 & 6.08 & 19.54 & 0.02 & 0.05 \\
\hline & Terumbu Saji & 29.37 & 34.00 & 8.29 & 6.11 & 19.67 & 0.07 & 0.06 \\
\hline & Hempasan Batin & 30.30 & 33.21 & 8.20 & 6.18 & 19.50 & 0.04 & 0.06 \\
\hline
\end{tabular}

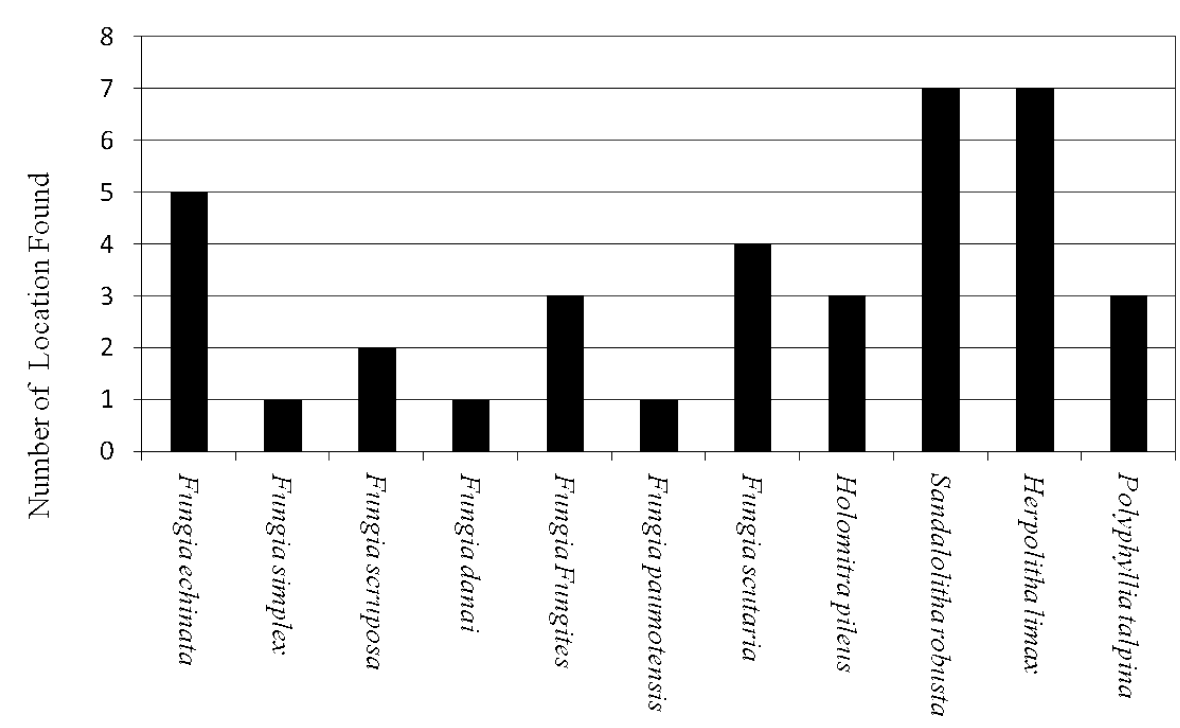

Species

Fig. 3. The total number of locations where fungiid coral were found.

Numbers of species (11 species) found in this study was very similar to the study done by Koh and Chou (1989) which identified 13 fungiid species belonging to five genera. Out of the 11 species recorded in this study, there were only six species which have been reported in southern Singapore. Lithophyllon undulatum was unique and only reported in Singapore and has not been reported by Veron (1993) during his survey covering all the reefs in Indo-Pacific. More research work is needed to map the distribution patterns of Fungiidae corals in the future. 
Table 4. Comparison of the species of fungiid corals reported by other authors

\begin{tabular}{|c|c|c|c|c|c|c|c|}
\hline \multirow[b]{2}{*}{ Genus } & \multirow[b]{2}{*}{ Species } & \multicolumn{6}{|c|}{ Authors } \\
\hline & & 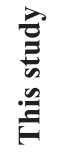 & 苛 & 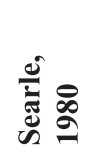 & 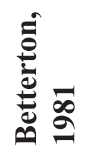 & ڤ & 苞 \\
\hline \multirow[t]{7}{*}{ Cycloseris } & Cycloseris costulata & & $\sqrt{ }$ & & & & \\
\hline & Cycloseris cyclolites & & $\sqrt{ }$ & & & & \\
\hline & Cycloseris erosa & & $\sqrt{ }$ & & & & \\
\hline & Cycloseris patelliformis & & $\sqrt{ }$ & & & & \\
\hline & Cycloseris sommervillei & & $\sqrt{ }$ & & & & \\
\hline & Cycloseris marginata & & $\sqrt{ }$ & & & & \\
\hline & Cycloseris vaughani & & $\sqrt{ }$ & & & & \\
\hline \multirow[t]{2}{*}{ Diaseris } & Diaseris distorta & & $\sqrt{ }$ & & & & \\
\hline & Diaseris fragilis & & $\sqrt{ }$ & & & & \\
\hline Heliofungia & Heliofungia actiniformis & & $\sqrt{ }$ & & & & \\
\hline \multirow[t]{17}{*}{ Fungia } & Fungia fungites & $\sqrt{ }$ & $\sqrt{ }$ & $\sqrt{ }$ & $\sqrt{ }$ & $\sqrt{ }$ & \\
\hline & Fungia horrida & & $\sqrt{ }$ & & & & \\
\hline & Fungia klunzingeri & & $\sqrt{ }$ & & & & \\
\hline & Fungia scruposa & $\sqrt{ }$ & $\sqrt{ }$ & & & $\sqrt{ }$ & \\
\hline & Fungia corona & & $\sqrt{ }$ & & & & \\
\hline & Fungia danai & $\sqrt{ }$ & $\sqrt{ }$ & & $\sqrt{ }$ & & \\
\hline & Fungia valida & & $\sqrt{ }$ & & & & \\
\hline & Fungia repanda & & $\sqrt{ }$ & $\sqrt{ }$ & $\sqrt{ }$ & $\sqrt{ }$ & \\
\hline & Fungia scabra & & $\sqrt{ }$ & & & $\sqrt{ }$ & \\
\hline & Fungia concinna & & $\sqrt{ }$ & & & $\sqrt{ }$ & \\
\hline & Fungia granulose & & $\sqrt{ }$ & & & & \\
\hline & Fungia scutaria & $\sqrt{ }$ & $\sqrt{ }$ & & $\sqrt{ }$ & & \\
\hline & Fungia moluccensis & & $\sqrt{ }$ & & & $\sqrt{ }$ & \\
\hline & Fungia paumotensis & $\sqrt{ }$ & $\sqrt{ }$ & & & $\sqrt{ }$ & \\
\hline & Fungia echinata & $\sqrt{ }$ & $\sqrt{ }$ & $\sqrt{ }$ & $\sqrt{ }$ & $\sqrt{ }$ & \\
\hline & Fungia simplex & $\sqrt{ }$ & $\sqrt{ }$ & & & & \\
\hline & Fungia actinoformis & & & $\sqrt{ }$ & $\sqrt{ }$ & $\sqrt{ }$ & \\
\hline \multirow{2}{*}{ Herpolitha } & Herpolitha limax & $\sqrt{ }$ & $\sqrt{ }$ & $\sqrt{ }$ & $\sqrt{ }$ & $\sqrt{ }$ & \\
\hline & Herpolitha weberi & & $\sqrt{ }$ & & & & \\
\hline Polyphyllia & Polyphyllia talpina & $\sqrt{ }$ & $\sqrt{ }$ & $\sqrt{ }$ & $\sqrt{ }$ & $\sqrt{ }$ & \\
\hline Halomitra & Halomitra pileus & $\sqrt{ }$ & $\sqrt{ }$ & & & & \\
\hline Sandalolitha & Sandalolitha robusta & $\sqrt{ }$ & $\sqrt{ }$ & & $\sqrt{ }$ & & \\
\hline \multirow[t]{2}{*}{ Lithophyllon } & Lithophyllon edwardsi & & $\sqrt{ }$ & & & & $\sqrt{ }$ \\
\hline & Lithophyllon undulatum & & & & & $\sqrt{ }$ & \\
\hline Podabacia & Podabacia crustacea & & $\sqrt{ }$ & $\sqrt{ }$ & $\sqrt{ }$ & $\sqrt{ }$ & \\
\hline Zoopilus & Zoopilus echinatus & & $\sqrt{ }$ & & & & \\
\hline \multicolumn{2}{|c|}{ Total No. of Species } & 11 & 34 & 7 & 10 & 13 & 1 \\
\hline
\end{tabular}


However, the number of fungiid species recorded in this study is higher compared to the studies by Searle (1980) and Betterton (1981), where only 7 and 10 species, respectively, were reported in their studies. This was because the reefs surveyed by the two scientists above were on the west and east coast of the Peninsular Malaysia, which were subjected to more tourism activities compared to the isolated reefs surveyed in this study. The high tourism activities had led to degradation in water quality (Ridzwan and De Silva, 1984). In addition, the reefs (Pulau Tioman and Johor Archipelago, located at east coast of Peninsular Malaysia; and Pulau Song-song, Pulau Pinang and Pulau Tikus, located at the Straits of Malacca) surveyed by Searle (1980) and Betterton (1981) were located very near the coastal areas, which were subjected to high sea traffic as well as discharge from the mainland, which had degraded the water quality of those reefs. Degradation of water quality eventually led to the degradation of the coral communities in the coral reef ecosystem.

The number of fungiid species recorded in this study is also higher compared to the study done by Scott (1984), where he has reported conspicuous absence of fungiids in the waters of Hong Kong except for one species, Lithophyllon edwarsi. Table 4 summarizes the comparison of this study with other studies on Fungiidae corals.

Limited dive per reefs were carried out during this expedition and this is insufficient to produce a comprehensive quantitative data of the surveyed reefs. More emphasis on the quantitative data will be carried out on selected reefs in the future expedition, as well as expanding the geographical area for the similar study on Fungiidae corals.

\section{Acknowledgments}

This research has been made possible due to the support of MOSTI (Ministry of Science, Technology and Innovation) and scientists from several institutes, universities and government departments. Special thanks to all of those who offered their expertise and useful information to make this research a success. Sincere gratitude to JSPS-NaGISA for providing sponsoring our participation in the NaGISA Westpac Conference in Jakarta, Indonesia.

\section{References}

APHA (American Public Health Association). 1992. Standard Methods for the Examination of Water and Wastewater. $18^{\text {th }}$ Edition. American Water Works Association and Water Pollution Control Federation, Washington, DC.

Betterton, C. 1981. A guide to the hard corals of Peninsular Malaysia (excluding genus Acropora). The Malayan Nature Journal, 34 (4), 171-336.

Chua, T.E. and Charles, J.K. (Eds) 1980. Coastal Resources of East Coast in Peninsular Malaysia. Universiti Sains Malaysia. 507 pp. In : Sheppard, C. and Well, S. M. (1988) Coral Reefs of the World. Vol. 2: Indian Ocean, Red Sea and Gulf, UNEP \& IUCN.

Koh, E.G.L. and Chou, L.M. 1989. The Mushroom Corals of Singapore. Department of Zoology, National University of Singapore, Singapore. Pp 45.

Ridzwan, A.R. and De Silva, M.W.R.N. 1984. Man's impact and recommendations for management of the coral reef ecosystems in Malaysia. Proc. MAB/COMAR Regional Seminar, Tokyo. Pp 131-134. In: Sheppard, C. \& Well, M. 1988. Coral Reefs of the World. Vol.2 : Indian Ocean, Red Sea and Gulf. UNEP \& IUCN.

Scott, P.J.B. 1984. The Corals of Hong Kong. Hong Kong University Press. Pp 20-21.

Searle, A.G. 1980. An Illustrated Key To Malayan Hard Corals. $2^{\text {nd }}$ Edition. The Malayan Nature Society, Kuala Lumpur. Pp 70.

Veron, J. E. N. 1993. Family Fungiidae. Corals of Australia and the Indo-Pacific, University of Hawaii Press. Pp 317-361. 